\title{
Controlled Trial of Phenobarbitone in Neonatal Jaundice
}

\author{
G. E. LEVIN, G. P. MCMULLIN ${ }^{\star}$, and A. N. MOBARAK \\ From the Departments of Pathology and Paediatrics, Royal Free Hospital, London
}

\begin{abstract}
Levin, G. E., McMullin, G. P., and Mobarak, A. N. (1970). Archives of Disease in Childhood, 45, 93. Controlled trial of phenobarbitone in neonatal jaundice. A single-blind controlled trial of phenobarbitone in the treatment of non-obstructive neonatal jaundice is reported. 24 babies were given phenobarbitone by mouth for 3 days from the first appearance of jaundice. 27 babies were given placebo linctus for the same period from the appearance of jaundice. There was a small but statistically significant difference between the mean serum bilirubin levels of the two groups 24 hours after starting treatment or placebo, the mean level of the control group being the higher. There was no significant difference in the mean serum bilirubin levels for the two groups initially or at 48 and 72 hours. The maximum recorded levels of serum bilirubin did not differ significantly between the two groups. It is concluded that phenobarbitone has no place in the management of established neonatal jaundice.
\end{abstract}

The effect of phenobarbitone on the conjugation of bilirubin has been shown in mice and in rats (Catz and Yaffe, 1962; Arias et al., 1963), in certain infants with congenital non-haemolytic hyperbilirubinaemia (Yaffe et al., 1966; Arias et al., 1963; Catz and Yaffe, 1962; Crigler and Gold, 1969), and in certain adults with chronic non-haemolytic hyperbilirubinaemia (Arias, 1962; Whelton, Krustev, and Billing, 1968). The possibility of an effect on physiological jaundice of the newborn was suggested originally by Trolle (1968a) in a retrospective study of the incidence of significant jaundice in the infants of mothers who had been receiving phenobarbitone during pregnancy. A prospective study by the same author confirmed this suggestion (Trolle, 1968b). Further confirmation of this effect has been provided by the reports of Maurer et al. (1968) and Ramboer, Thompson, and Williams (1969). All these studies showed that phenobarbitone given to the mothers during pregnancy was effective in lowering the incidence or degree of jaundice in their newborn offspring. A retrospective study by Walker, Hughes, and Barton (1969) was at variance with these findings, but in this study the doses of phenobarbitone used were perhaps too small. Direct administration

\footnotetext{
Received 21 July 1969.

* Present address: Nottingham Children's Hospital Chestnut Grove, Nottingham, NG3 5AF.
}

of phenobarbitone to newborn infants has also been tried. Trolle (1968b) showed a significant effect on the incidence of neonatal jaundice when the phenobarbitone was given from the first day of life: Other studies have shown no significant difference in serum bilirubin levels between control infants and infants treated with phenobarbitone before or after the appearance of jaundice (Ramboer et al., 1969; McMullin, 1968; Cunningham, Mace, and Peters, 1969). The subject has recently been reviewed by Wilson (1969).

The present report describes a controlled singleblind trial of phenobarbitone in the treatment of newborn infants with non-obstructive hyperbilirubinaemia.

\section{Material and Methods}

All babies born in the maternity department of the Royal Free Hospital were examined daily for jaundice. Those babies who manifested definite jaundice were allocated to treatment or control group according to the ward in which they were nursed. The order of the wards in which treatment or placebo was given was later reversed, so that the numbers of infants who received treatment and the numbers who received placebo were approximately equal in all four maternity wards. Infants in the treated group received phenobarbitone. This was dispensed in linctus simplex in a concentration of $1 \mathrm{mg} . / \mathrm{ml}$. The control group received linctus simplex only. The dosage schedule for treated and control groups alike was as follows: babies over $2.5 \mathrm{~kg}$., $5 \mathrm{ml}$. 
8 hourly; babies under $2.5 \mathrm{~kg}$. and over $1.7 \mathrm{~kg} ., 5 \mathrm{ml}$. 12 hourly; and babies under $1.7 \mathrm{~kg} ., 5 \mathrm{ml}$. daily.

The knowledge of which linctus contained phenobarbitone was kept by the hospital pharmacist until completion of the trial. Treatment or placebo was ordered simply as treatment A or treatment B.

Blood was taken by heel-prick for serum bilirubin estimation as soon as possible after the appearance of jaundice and before starting treatment or placebo. Treatment or placebo was started as soon as the first blood specimen had been taken for serum bilirubin estimation and was continued for three days. Further specimens of blood were taken daily during the treatment period or until the serum bilirubin level showed a consistent fall, whichever was longer.

Sera were estimated for total and conjugated bilirubin by the method of Jendrassik, Grof, and Nosslin as modified by Michaelsson (1961). $10 \mu \mathrm{l}$. serum were used in the assay, and all estimations were performed in duplicate within 24 hours of sample collection. The coefficient of variation for the assay was found to be $4 \%$. All the estimations were carried out by one of us (G.E.L.).

Babies with rhesus incompatibility were excluded from this study. One baby in the control group required exchange transfusion after one day on placebo because his serum bilirubin level rose to $24 \mathrm{mg}$. $/ 100 \mathrm{ml}$. He has also been excluded from the trial. This left 24 babies in the treatment group and 27 babies in the control group.
Table I shows the comparison of the two groupg for birthweight, gestational age, age at entry to the triä, and weight gain during the period of the trial. The were 3 babies with birthweights under $2 \cdot 25 \mathrm{~kg}$. in the treated group and 2 such babies in the control group. This gave a slightly lower mean birthweight in the treated group than in the control group, but this diffecence is not significant. When babies weighing le than $2.25 \mathrm{~kg}$. at birth are excluded the mean birt $\bar{k}$ weights for the two groups are more nearly equaf. In other respects the two groups are similar.

\section{Results}

Table II shows the serum bilirubin levels in the two groups on each day of the trial and comparis the maximum serum bilirubin levels in the two groups and the differences between the initial and final bilirubin levels in the two groups. The difference between the mean bilirubin levels 20 hours after starting treatment or placebo is statisti cally significant at the $p<0.05$ level. In respegt of all the other variables the differences between the groups are quite insignificant.

Three babies in each group had rising bilirubig levels at the end of three days. The maximum serum bilirubin levels naturally occurred after the trial period in these 6 babies. In 11 babies in the

TABLE I

Mean Birthweight, Gestational Age, Age at Entry to Trial, and Weight Gain during Trial in Treated Untreated Infants

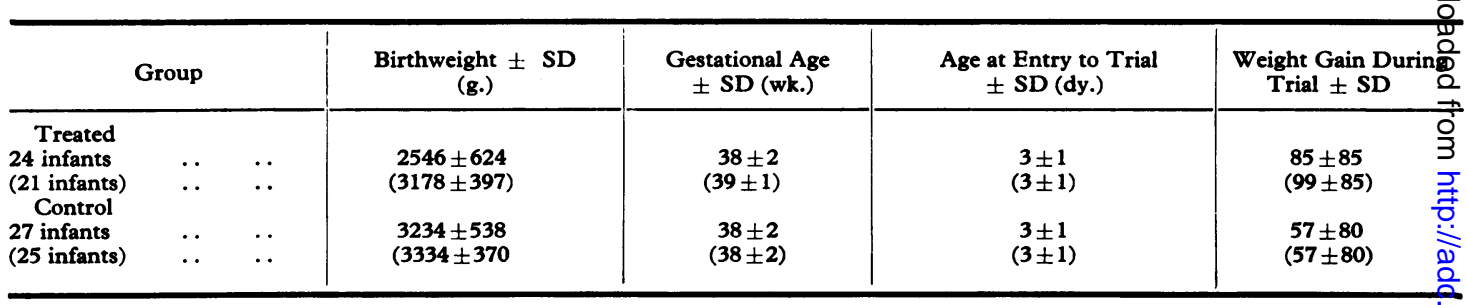

Figures in parentheses represent corresponding values for babies of birthweight over $2 \cdot 25 \mathrm{~kg}$.

TABLE II

Mean Serum Bilirubin Levels on Each Day of Trial, Maximum Serum Bilirubin Levels and Differencess between Means for Initial and Final Days in Treated and Untreated Infants

\begin{tabular}{|c|c|c|c|c|c|c|}
\hline \multirow[b]{2}{*}{ Group } & \multicolumn{6}{|c|}{ Mean Serum Bilirubin Levels (mg./100 ml.) $\pm S D$} \\
\hline & Day 0 & Day 1 & Day 2 & Day 3 & Maximum & $\begin{array}{c}\text { Difference } \\
\text { Day 0-Day } 3\end{array}$ \\
\hline $\begin{array}{l}\text { Treated } \\
\text { Control }\end{array}$ & $\begin{array}{c}7 \cdot 7 \pm 2 \cdot 4 \\
(7 \cdot 9 \pm 2 \cdot 4) \\
8 \cdot 1 \pm 2 \cdot 8 \\
(8 \cdot 0 \pm 2 \cdot 9)\end{array}$ & $\begin{array}{l}7 \cdot 6^{\star} \pm 2 \cdot 7 \\
\left(7 \cdot 6^{\star} \pm 2 \cdot 8\right) \\
9 \cdot 0^{\star} \pm 2 \cdot 4 \\
\left(8 \cdot 9^{\star} \pm 2 \cdot 3\right)\end{array}$ & $\begin{array}{l}8 \cdot 0 \pm 3 \cdot 6 \\
(8 \cdot 2 \pm 3 \cdot 5) \\
7 \cdot 8 \pm 2 \cdot 9 \\
(7 \cdot 8 \pm 2 \cdot 9)\end{array}$ & $\begin{array}{c}7 \cdot 4 \pm 3 \cdot 8 \\
(6 \cdot 7 \pm 3 \cdot 4) \\
7 \cdot 1 \pm 3 \cdot 2 \\
(7 \cdot 2 \pm 3 \cdot 2)\end{array}$ & $\begin{array}{c}9 \cdot 5 \pm 3 \cdot 1 \\
(9 \cdot 4 \pm 3 \cdot 0) \\
9 \cdot 8 \pm 2 \cdot 5 \\
(9 \cdot 8 \pm 2 \cdot 5)\end{array}$ & $\begin{array}{c}0 \cdot 3 \pm 3 \cdot 1 \\
(1 \cdot 2 \pm 3 \cdot 3) \\
0 \cdot 9 \pm 3 \cdot 3 \\
(0 \cdot 8 \pm 3 \cdot 3)\end{array}$ \\
\hline
\end{tabular}

$\star \mathrm{p}<0.05$.

Figures in parentheses represent corresponding values for babies of birthweight over $2 \cdot 25 \mathrm{~kg}$. 
treated group and 12 babies in the control group the maximum bilirubin level recorded was the initial one. One cannot therefore properly speak of a peak level in these cases. In only 6 babies did definite jaundice persist beyond the fourth day after entering the trial. There is, therefore, no analysis of the difference in duration of jaundice between the two groups.

The incidence of signs and symptoms of disease has been compared in the two groups. These included lethargy, irritability, difficulty with feeding, rashes, and splenomegaly. One baby in the treated group showed some evidence of irritability; one small premature baby in the same group was difficult to feed. In both cases the symptoms were present before the start of treatment. In the control group there were 2 babies with unexplained splenomegaly, 2 babies were difficult to feed, and 1 developed a septic rash two days after the trial period. One baby in the treated group was the offspring of a diabetic mother and had all the appearances of a diabetic's baby.

\section{Discussion}

The object of this trial was to determine whether there was any clinical benefit to be gained from instituting treatment with phenobarbitone in neonates with early physiological jaundice. This study shows conclusively that there is not-at any rate with these doses (approximately $5 \mathrm{mg}$. $/ \mathrm{kg}$. per day)-since there was no significant difference between the peak or the three-day levels of serum bilirubin in the two groups. This confirms, amplifies, and completes the study by Cunningham et al. (1969), who used phenobarbitone in a dose of $8 \mathrm{mg}$. $/ \mathrm{kg}$. per day. It remains theoretically possible that larger doses of phenobarbitone might have some effect in lowering the serum bilirubin levels more rapidly or preventing further rises in serum bilirubin levels. In view of the complete absence of any effect with the doses so far used, it seems, however, very unlikely that such an effect could be achieved without inducing symptoms such as drowsiness and difficulty with feeding. There is also the theoretical possiblity that higher doses of phenobarbitone might compete with bilirubin for binding to serum albumin.

There remains the question of the feasibility or desirability of giving infants phenobarbitone in utero or from the first day of life. Ramboer et al. (1969) have suggested that mothers whose unborn infants are regarded as being specially at risk of hyperbilirubinaemia might be given phenobarbitone from the 32nd week of pregnancy. This would include rhesus negative mothers with antibodies and mothers of twins or with a history of previous premature deliveries. It might also include diabetic mothers. The evidence from the work of Trolle (1968b) and Ramboer et al. (1969) that such a policy would decrease the incidence of severe neonatal jaundice is highly suggestive, though a controlled trial involving only such high risk groups remains to be done.

The value of giving infants phenobarbitone from the day of birth is more doubtful. The effects shown so far by Trolle and by Ramboer et al. are of borderline significance. It is again possible that slightly larger doses might be more obviously effective. Trolle (1968c) has reported a possible reduction in first week mortality in small premature babies treated with a single dose of phenobarbitone on the day of birth, though the statistical validity of this effect has been questioned (Robinson, 1968). A larger trial of slightly larger doses of phenobarbitone in small premature babies and babies of diabetic mothers is perhaps justified. Mildly affected babies with rhesus incompatibility might also be included.

We wish to thank Professor C. P. Douglas, Miss J. A. M. Moore, Miss K. M. Robinson, and Miss L. Epsztejn for permission to study the infants under their care, also Mr. J. Meertins, the hospital pharmacist, for his assistance, and Mrs. M. E. Monk-Jones for her advice and help with the statistical analysis of our results.

\section{REFERENCES}

Arias, I. M. (1962). Chronic unconjugated hyperbilirubinemia without overt signs of hemolysis in adolescents and adults. Fournal of Clinical Investigation, 41, 2233.

_- Gartner, L., Furman, M., and Wolfson, S. (1963). Studies on the effect of several drugs on hepatic glucuronide formation in newborn rats and humans. Annals of the New York Academy of Sciences, 111, 274.

Catz, C., and Yaffe, S. J. (1962). Pharmacological modification of bilirubin conjugation in the newborn. (Abstr.) American Fournal of Diseases of Children, 104, 516.

Crigler, J. F., Jr., and Gold, N. I. (1969). Effect of sodium phenobarbital on bilirubin metabolism in an infant with congenital nonhemolytic, unconjugated hyperbilirubinemia, and kernicterus. Fournal of Clinical Investigation, 48, 42.

Cunningham, M. D., Mace, J. W., and Peters, E. R. (1969). Clinical experience with phenobarbital in icterus neonatorum. Lancet, 1, 550.

McMullin, G. P. (1968). Phenobarbitone and neonatal jaundice. Lancet, 2, 978.

Maurer, H. M., Wolf, J. A., Finster, M., Poppers, P. J., Pantuck, E., Kuntzmann, R., and Conney, A. H. (1968). Reduction in concentration of total serum-bilirubin in offspring of women treated with phenobarbitone during pregnancy. ibid., 2, 122.

Michaelsson, M. (1961). Bilirubin determination in serum and urine. Scandinavian Fournal of Clinical and Laboratory Investigation, 13, suppl., 56.

Ramboer, C., Thompson, R. P. H., and Williams, R. (1969). Controlled trials of phenobarbitone therapy in neonatal jaundice. Lancet, 1, 966.

Robinson, R. J. (1968). Effect of phenobarbitone on low-birthweight infants. Lancet, $2,1243$.

Trolle, D. (1968a). Phenobarbitone and neonatal icterus. ibid., $1,251$. 
- (1968b). Decrease of total serum-bilirubin concentration in newborn infants after phenobarbitone treatment. ibid., 2, 705. (1968c). A possible drop in first-week-mortality rate for low-birth-weight infants after phenobarbitone treatment. ibid., 2, 1123.

Walker, W., Hughes, M. I., and Barton, M. (1969). Barbiturate and hyperbilirubinaemia of prematurity. ibid., 1, 548.

Whelton, M. J., Krustev, L. P., and Billing, B. H. (1968). Reduction in serum bilirubin by phenobarbital in adult unconjugated hyperbilirubinemia. Is enzyme induction responsible? American fournal of Medicine. 45, 160.
Wilson, J. T. (1969). Phenobarbital in the perinatal perfod. Pediatrics, 43, 324.

Yaffe, S. J., Levy, G., Matsuzawa, T., and Baliah, T. (1966) Enhancement of glucuronide-conjugating capacity in a hyprbilirubinemic infant due to apparent enzyme induction "by phenobarbital. New England fournal of Medicine, 275, 146 穴

Correspondence to Dr. G. P. McMullin, Nottingh Children's Hospital, Chestnut Grove, Nottingh NG3 5AF.

The following articles will appear in future issues of this journal:

Cardiovascular Responses to Postural Changes in the Neonate. By C. G. Picton-Warlow and Floremee E. Mayer.

Effects of Short-term High-carbohydrate Feeding on Serum Triglyceride of Children with Familfal Hypercholesterolaemia. By M. M. Segall, I. Tamir, A. S. Fosbrooke, J. K. Lloyd, and O. H. Wolff Maternal Milk and Serum Vitamin B12, Folic Acid, and Protein Levels in Indian Subjects. By V. \& Jathar, S. A. Kamath, M. Parikh, D. V. Rege, and R. S. Satoskar.

Paediatric Research Society, Proceedings of a Meeting held at the Welsh National School of Medicirie, Cardiff, 3 and 4 October, 1969.

Personal Practice: Treatment of the Poisoned Child. By David H. S. Reid.

Congenital Lactose Malabsorption. By B. Levin, J. M. Abraham, E. Ann Burgess, and Patricia G. Wallis. Carmine as an Index of Transit Time in Children with Simple Constipation. By S. B. Dimson.

Breast Milk Jaundice: effect of 3-x, 20- $\beta$-Pregnanediol on Bilirubin Conjugation by Human Liver.

B. P. F. Adlard and G. H. Lathe.

Diphenoxylate Therapy in the Diarrhoea of Malnourished Infants. By J. Bitar, S. S. Naijar, and R. Y. Asfour.

Management of Congenital Aortic Stenosis. By J. M. Reid, E. N. Coleman, and J. G. Stevenson. Metronidazole Combined with Dihydroemetine in the Treatment of Children with Amoebic Liver Abs\&ess. By J. N. Scragg and S. J. Powell.

Treatment of Children with Acute Amoebic Dysentery: Comparative Trial of Metronidazole against combination of Dehydroemetine, Tetracycline, and Diloxanide Furoate. By C. J. Rubidge, J. N. Scragg, and S. J. Powell.

Coincidence of Congenital Malformation and Embryonic Tumours of Childhood. By Colin L. Berig, Jean Keeling, and Clare Hilton.

Immunoglobulins in Protein-Calorie Malnutrition. By C. E. Watson and C. Freesemann.

Staphylococcal Pericarditis with Cardiac Tamponade in Children. By S. K. Sanyal, I. Kaur, V. Hoo M. K. Thapar, and S. Vaishnava.

Treatment of Ventriculitis with Gentamicin and Cloxacillin in Infants born with Spina Bifida. By $\$$ Lorber, S. C. Kalhan, and B. Mahgrefte.

Short Report: Dermatitis Herpetiformis in a Treated Coeliac Child. By A. S. McNeish, N. GordÖ Fraser, and W. Neil Morley.

Short Report: Arthrogryposis Following the Treatment of Maternal Tetanus with Muscle Relaxants.

R. H. Jago.

Adrenal Cortical Function in Children on Steroids. By J. A. Kuzemko and J. G. Lines.

Valgus Knee Deformities in Children with Juvenile Chronic Polyarthritis Treated by Epiphysial Staplino By B. M. Ansell, G. P. Arden, and I. McLennan.

Bronchial Provocation Tests in Asthma. By Kjell Aas.

Infantile Renal Tubular Acidosis Due to Mercury Poisoning. By P. Husband and W. J. D. McKellar. Apnoea after THAM Administration in the Newborn. By N. R. C. Roberton.

Urinary Excretion of Phosphate in Normal Children. By N. C. Thalassinos, B. Leese, S. C. Latham, añd G. F. Joplin.

Urinary Infection in Two Selected Neonatal Populations. By P. E. Gower, P. Husband, J. C. Colemaw and G. J. A. I. Snodgrass.

Review Article: Pyelonephritis Lenta: a consideration of Childhood Urinary Infection as the Forerunner of Renal Insufficiency in Later Life. By Malcolm McGregor.

Short Report: Familial Duodenal Atresia. By Moshe Berant and David Kahana.

Annotation: Antenatal Paediatrics by Amniocentesis. By C. O. Carter. 